\title{
Broadly neutralizing antibodies and vaccine design against HIV-1 infection
}

\author{
Qian Wang, Linqi Zhang (凶) \\ Comprehensive AIDS Research Center, Beijing Advanced Innovation Center for Structural Biology, Collaborative Innovation Center for \\ Diagnosis and Treatment of Infectious Diseases, Department of Basic Medical Sciences, School of Medicine, Tsinghua University, Beijing \\ 100084, China
}

(C) The Author(s) 2019. This article is published with open access at link.springer.com and journal.hep.com.cn

\begin{abstract}
Remarkable progress has been achieved for prophylactic and therapeutic interventions against human immunodeficiency virus type I (HIV-1) through antiretroviral therapy. However, vaccine development has remained challenging. Recent discoveries in broadly neutralizing monoclonal antibodies (bNAbs) has led to the development of multiple novel vaccine approaches for inducing bNAbs-like antibody response. Structural and dynamic studies revealed several vulnerable sites and states of the HIV-1 envelop glycoprotein (Env) during infection. Our review aims to highlight these discoveries and rejuvenate our endeavor in HIV-1 vaccine design and development.
\end{abstract}

Keywords HIV-1; broadly neutralizing antibodies; Env conformational states; vaccine design; SOSIP

\section{Introduction}

Human immunodeficiency virus type I (HIV-1) is the cause of the global epidemic of acquired immunodeficiency syndrome (AIDS) [1,2]. Since its discovery in the early 1980s, HIV-1 has infected more than 70 million individuals and caused 35 millions deaths worldwide [3]. Approximately 1.2 million of all infected cases originated from China [4,5]. Antiretroviral therapy can achieve sustained viral suppression, extend the life span of infected individuals, and reduce HIV transmission [6,7]. However, the establishment and persistence of a latent viral reservoir in infected patients pose a huge barrier for eliminating the virus and ultimately curing this disease $[8,9]$.

A safe and effective vaccine is a remarkable prospect for blocking HIV-1 infection. However, the high degrees of sequence and structural diversity within and between infected individuals enable viral escape from immune recognition. To date, traditional vaccine approaches have failed to overcome HIV-1 diversity despite the remarkable success against a large array of pathogens with minimal variability [10]. Out of over 100 vaccine trials, only the

Received August 4, 2019; accepted September 7, 2019

Correspondence: Linqi Zhang, zhanglinqi@tsinghua.edu.cn
RV144 trial has achieved positive yet moderate protection $(31.2 \%)$ [11]. Therefore, a sophisticated and rational approach is needed to develop protective vaccines against HIV-1. The major focus of vaccine design approaches is the envelope glycoprotein (Env) because it is the sole target for broadly neutralizing antibodies (bNAbs) $[12,13]$. Technical advancements in antibody technology have facilated identification of a new generation of bNAbs targeting various regions of HIV-1 Env [13-15]. Structure and function studies on specific epitope and conformational states recognized by these bNAbs have provided unprecedented opportunities for vaccine design to induce bNAb-like antibody response.

\section{HIV-1 bNAbs}

HIV-1 bNAbs can neutralize the majority of HIV-1 strains from diverse genetic and geographic backgrounds. bNAbs are broadly classified into two major generations on the basis of their neutralization activity and the time of their initial isolation [16]. First-generation bNAbs were isolated in the 1990s and have exhibited limited neutralization potency and breadth. However, new potent and broad neutralization antibodies have been isolated since 2009 and now represent second-generation bNAbs. 


\section{First-generation bNAbs}

First-generation bNAbs include b12, 2G12, 2F5, and 4E10, which were isolated through phage surface display and Epstein-Barr virus transformation of $\mathrm{B}$ cells derived from HIV-1-infected patients [17-20]. The molecular characterization of these antibodies helped identify several vulnerable sites on gp120 and gp41 of HIV-1 Env. These sites include the CD4 binding site (CD4bs) targeted by b12 [17,21], OD-glycans by 2G12 [18], and membrane proximal external region (MPER) of gp41 by 4E10 and 2F5 $[19,20]$. Although these antibodies are relatively weak in breadth and potency, the passive transfer of high doses of b12, 2G12, 2F5, and 4E10 produced impressive levels of protection against simian-human immunodeficiency viruses (SHIVs) in rhesus macaques [22-27]. Given that b12 is derived from a phage display antibody, its heavy and light chain combinations are considered unnatural [17]. $2 \mathrm{G} 12$ has an atypical structure, especially in the combining sites of the antigen-binding fragment (Fab) $[18,28]$. 2F5 and 4E10 are polyreactive [29,30]. Despite encouraging results in animal models, clinical trial data revealed that the combinations of these first-generation bnAbs failed to effectively suppress viremia in humans [31].

\section{Second-generation bNAbs}

Approximately $10 \%-25 \%$ of HIV-1-infected individuals exhibit broad and potent neutralizing activities against a diverse panel of circulating virus strains [32-37]. Cloning of antigen-specific antibodies from naturally occurring B cells has helped obtain dozens of second-generation bNAbs from HIV-1-infected individuals $[13,14]$. Sequence mapping and structural analysis of antibody and antigen complexes have led to the identification of several vulnerable targets on HIV-1 Envs, such as N-glycanassociated epitopes on the V1/V2 (PG9, PGT145) and V3 regions (PGT121, 10-1074), CD4bs (VRC01, N6, 3BNC117), gp120/gp41 interface (35O22, 8ANC195), fusion peptide (VRC34.01, ACS202), silent face center (VRC-PG05, SF12), and MPER on gp41 (10E8). The specific epitopes targeted by each of these bNAbs and their unique features are summarized in Table 1 and Fig. 1. Recent developments in the use of bnAbs for HIV-1 prevention and treatment are outlined in Fig. $2[38,39]$.

\section{V1V2}

The apex V1V2 of Env is masked by glycans and variable loops [40,41]. Structural analysis shows that V1V2specific antibodies, such as PG9, PG16, CH01-04, PGT141-145, PGDM1400-1412, and CAP256VRC26.01-33, utilize the long, anionic complementaritydetermining region 3 loops of heavy chain (CDRH3) to penetrate the glycan shield and interact with a quaternary epitope formed by V1V2 and N156/N160 glycans [42-46].

\section{V3-glycan}

Glycan-V3-directed bNAbs, such as PGT121- and PGT128-like antibodies, come in contact with a highmannose patch at/near N332 in the V3 region through protruding loop regions with various angles [44,47]. Common examples in this category include PGT121-like antibodies, which are bound to the base, and PGT128-like antibodies, which interact with the C-terminal end of the V3 loop [47-49]. These antibodies prevent HIV-1 infection by interfering with CD4 and CCR5 co-receptor binding capabilities $[48,50]$.

\section{CD4bs}

CD4 molecules on the cell surface serve as primary binding targets for HIV-1 Env gp120 [51,52]. CD4bs is functionally conserved and structurally recessed on gp120, surrounded by multiple glycans. Despite its recessed nature, $\mathrm{CD} 4 \mathrm{bs}$ is accessible to CD4 molecules and various CD4bs-specific antibodies [53]. CD4bs exhibits a good amount of heterogeneity in its sequence and structure among HIV-1 strains but can induce the largest number of known bNAbs during infection [54]. Several CD4bs antibodies neutralize over $90 \%$ of HIV-1 strains, including VRC01, VRC07, N6, 3BNC117, and N49P [55-58]. One of the most potent ones is the recently identified N49P antibody that can neutralize nearly $100 \%$ of a global panel comprising 117 pseudoviruses [55]. X-ray crystallographic analysis showed that N49P7 could bypass the CD4bs Phe43 cavity and reach deeply into the highly conserved residues of layer 3 of the gp120 inner domain. These unique features may explain the extreme potency and breadth of this antibody. In addition, these CD4bs bNAbs share some common features in mode of action and compostion of variable domains such as mimicking CD4 to achieve their known distinguished breadth [59], using VH1-2 germline origin genes of the heavy chain, and having a short five-amino-acid complementarity determining region 3 of the light chain (CDR L3) [55-59]. However, many resistant strains are against this class of antibodies in naturally infected individuals [60]. Treatment strategies based on CD4bs antibodies must overcome such resistance to achieve optimal clinical outcomes.

\section{MPER}

MP ER-specific antibody 10E8, which was isolated by Huang et al. in 2012, neutralized approximately $98 \%$ of tested viruses and had a geometric mean $\mathrm{IC}_{50}$ value of $0.352 \mu \mathrm{g} / \mathrm{mL}$ [61]. Different from the first-generation MPER-directed bNAbs $2 \mathrm{~F} 5$ and 4E10, 10E8 is not 


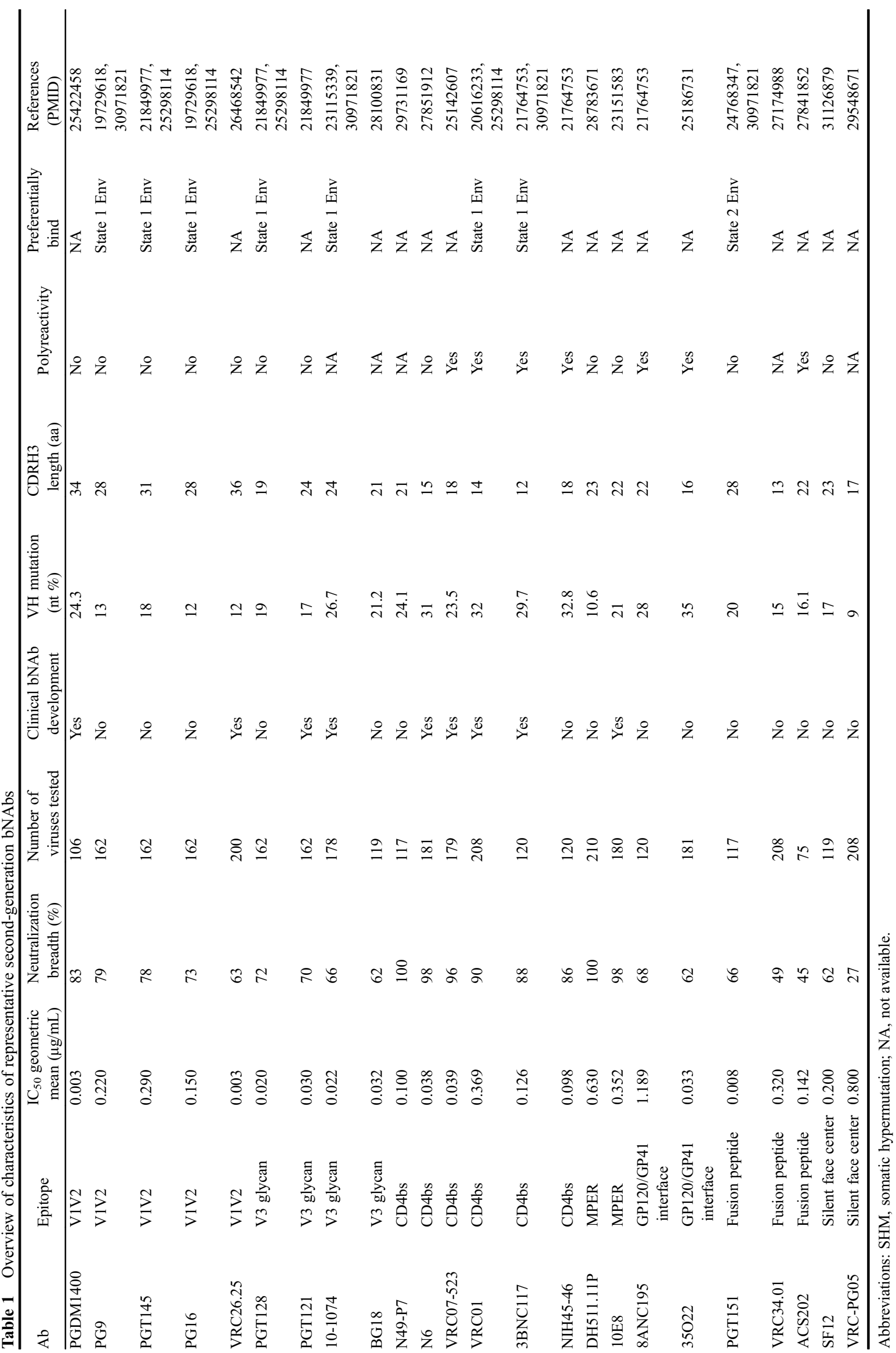



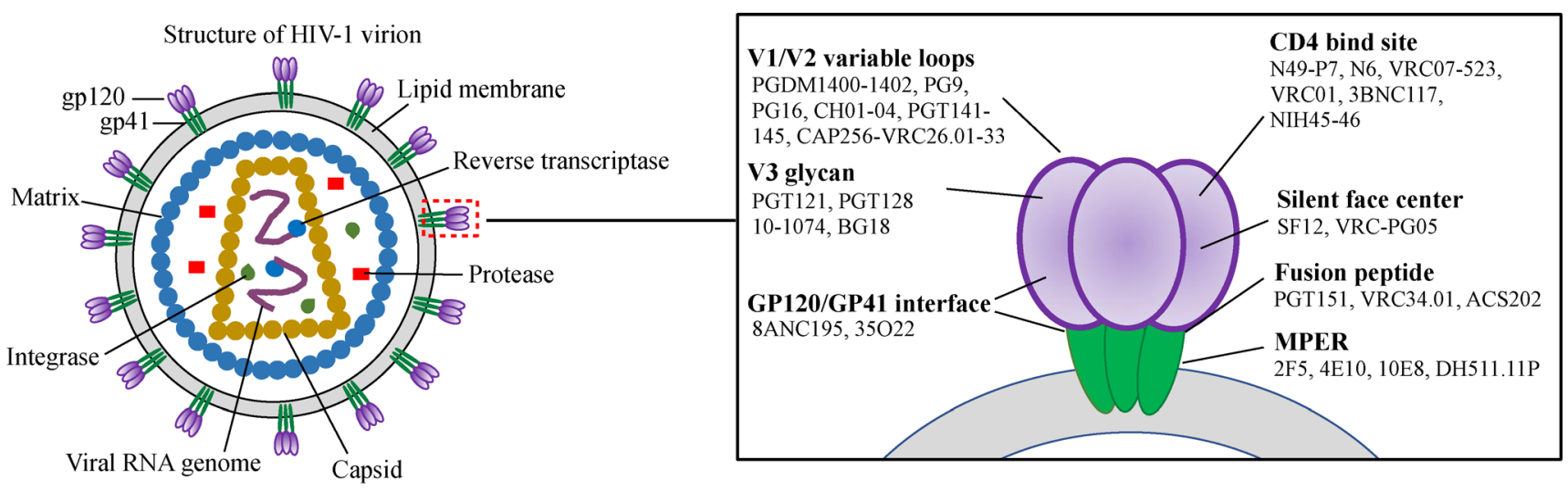

Fig. 1 Schematic diagram of HIV-1 and epitopes for bNAbs on trimeric HIV envelope spike glycoproteins.

\begin{tabular}{|c|c|c|c|c|c|}
\hline Epitope & Antibody & Pre-clinical & Phase I & Phase II & Phase IIb/III \\
\hline \multirow{5}{*}{ V1/V2-glycan } & PGT145 & & & & \\
\hline & PG16 & & & & \\
\hline & VRC26.25-LS & & & & \\
\hline & PG9 & & & & \\
\hline & PGDM1400 & & & & \\
\hline \multirow{5}{*}{ V3-glycan } & PGT128 & & & & \\
\hline & PGT121-LS & & & & \\
\hline & 10-1074-LS & & & & \\
\hline & PGT121 & & & & \\
\hline & $10-1074$ & & & & \\
\hline \multirow{8}{*}{ CD4bs } & NIH45-46 & & & & \\
\hline & N49-P7 & & & & \\
\hline & N6 & & & & \\
\hline & VRC07-523LS & & & & \\
\hline & 3BNC117-LS & & & & \\
\hline & $3 \mathrm{BNC} 117$ & & & & \\
\hline & VRC01-LS & & & & \\
\hline & VRC01 & & & & \\
\hline \multirow[b]{2}{*}{ MPER } & DH511.11P & & & & \\
\hline & 10E8V-LS & & & & \\
\hline \multirow{2}{*}{$\begin{array}{c}\text { GP120/GP41 } \\
\text { interface }\end{array}$} & 8 ANC195 & & & & \\
\hline & $35 \mathrm{O} 22$ & & & & \\
\hline \multirow{3}{*}{$\begin{array}{l}\text { Fusion } \\
\text { peptide }\end{array}$} & PGT151 & & & & \\
\hline & VRC34.01 & & & & \\
\hline & ACS202 & & & & \\
\hline \multirow{2}{*}{$\begin{array}{c}\text { Silent face } \\
\text { center }\end{array}$} & $\mathrm{SF} 12$ & & & & \\
\hline & VRC-PG05 & & & & \\
\hline
\end{tabular}

Fig. 2 Current status of bNAb development in preclinical and clinical studies.

phospholipid- or auto-reactive and recognizes the highly conserved helix at the $\mathrm{C}$-terminal half of the MPER region that is proximal to the transmembrane region. The development of these antibodies and detailed potential strategies of inducing 10E8-like antibody through vaccination have been recently highlighted. A multimeric founder MPER can stimulate B cells bearing the unmutated common ancestor of the 4E10-like antibody VRC42. Therefore, immunogens containing the specific founder MPER can be utilized to stimulate naive B cells to initiate 4E10- and 10E8-like antibodies [62].

\section{GP120/GP41 interface}

35O22, which targets the gp120/gp41 interface, was isolated by Huang et al. in 2014 [63]. This antibody neutralized $62 \%$ of 181 tested pseudoviruses with a geometric mean $\mathrm{IC}_{50}$ value of $0.033 \mu \mathrm{g} / \mathrm{mL}$. Similar to $35 \mathrm{O} 22,8 \mathrm{ANC} 195$ also recognized the subunit interface of the prefusion-closed conformation of Env [64]. Both of these antibodies are immune to the conformational change of Env triggered by CD4 molecules, while other bnAbs are not. 8ANC195 can even bind the gp120 monomer in the absence of gp41 [65].

\section{Fusion peptide}

The 15 to 20 hydrophobic residues, termed fusion peptide, at the $\mathrm{N}$ terminus of the gp41 subunit are another vulnerable site recognized by bNAbs such as VRC34.01, 
PGT151, and ACS202 [66-68]. The residual sequences of fusion peptide are highly conserved and strain-specific [66]. Interestingly, ACS202 shows broadly neutralization activity against recombinant CRF01_AE viruses, while VRC34.01 and PGT151 fails [66-68]. VRC34.01, PGT151, and ACS202 can approach fusion peptide from various angles and function in multiple conformations of fusion peptide [69]. However, the generation of these antibodies during infection and their mechanism of neutralization remain largely unknown. Given their relatively conserved nature among circulating HIV-1, fusion peptided represents a promising vaccine candidate $[70,71]$.

\section{Silent face}

The silent face represents a relatively new target for generating bNAbs. This site is not substantially affected by glycan alteration and therefore can maintain sensitivity to antibody recognition and neutralization. However, the potency and breadth of this class of antibodies are generally less than those of the abovementioned bNAbs. For example, the VRC-PG05-like antibody, which targets the center of the silent face, shows $\sim 0.8 \mu \mathrm{g} / \mathrm{mL}$ (geometric mean $\mathrm{IC}_{50} \mathrm{~s}$ ) potency and $27 \%$ breadth [72]. In comparison, the recently isolated SF12 antibody shows greater potency of $\sim 0.20 \mu \mathrm{g} / \mathrm{mL}$ (geometric mean $\mathrm{IC}_{50} \mathrm{~s}$ ) and $62 \%$ breadth [73]. Nevertheless, these two antibodies highlight the silent face epitope as a new and potential target for vaccinedirected response.

\section{Common features of HIV-1 bNAbs}

HIV-1 bNAbs can neutralize diverse HIV-1 strains that possess one or more unusual traits, such as uncommon recombination patterns, extensive somatic hypermutation (SHM), long IgH CDR3s, and self- or polyreactive nature [74,75]. The high levels of mutation and long CDRH3 are the result of multiple rounds of affinity maturation and selection through interaction with evolving Envs in the germinal center. Virus escape sometimes induces the development of neutralizing antibodies in an unusual, coevolutionary manner $[62,76,77]$. This phenomenon highlights the complexity in the process and pattern of bNAb development. Not all Envs or conformational states are equal to binding and neutralization by bNAbs. Most bNAbs are prone to binding conformational state 1 of Envs, indicating conformational vulnerability in addition to the epitope vulnerability of the Env of HIV-1 [78].

\section{High SHM}

HIV-1 bNAbs directed at the Env of the virus are rarely developed in acutely infected individuals and typically emerge only after several years of infection [79,80]. HIV-1 bNAbs have high levels of SHM as a result of multiple rounds of antigen recognition and stimulation [15,81]. For example, manifold improvement in the neutralizing potency and breadth of HIV-1 bNAbs has been observed after 40-100 gene somatic mutations in the heavy chain. In constrast, most human antibodies often carry 10-20 gene mutations [82,83]. Amino acid variation greater than 30\%$40 \%$ has been observed in the heavy-chain bNAbs targeting CD4bs [15]. In addition to the expected region of CDRs, mutations also appear in the framework regions (FWRs) of these bNAbs [84]. A FWR is typically less tolerant of mutations because of the potential structural destruction of the variable domain.

In addition to amino acid substitutions, HIV-1 bNAbs present a large number of length polymorphisms, such as insertion and deletions, which could be up to sevenfold higher than those of most human antibodies [85]. Insertions and deletions could be observed in the heavy and light chains of CDRs and FWRs [85]. When HIV-1 bNAbs are reverted to their germline ancestor sequences, their neutralization and binding abilities to most HIV-1 Envs are reduced and even completely lost [86].

The exact mechanism for the high mutation of HIV-1 bNAbs remains unclear. One hypothesis is that only some specific HIV-1 Envs can activate and trigger germline antibody-expressing B cells. The activated B cells are further stimulated by the continuously evolving and mutating Envs during infection. This phenomenon persists until the antibody gene has a sufficient and appropriate number of mutations that can recognize diverse Env variants. Another hypothesis is that the B cells expressing germline antibodies first engage with non-HIV-1 antigen and then develop cross-reactivity with HIV-1 Envs through a series of mutations [87]. Both hypotheses have some supporting evidence, although they are not necessarily mutually exclusive.

\section{Long CDRH3}

HIV-1 bNAbs generally have long CDRH3 that enables the penetration of the glycan shield of the envelope [15]. Most human antibody CDRH3s range from 8 to 16 amino acids in length, whereas HIV-1-specific antibodies average at approximately 17.8 amino acids. In particular, HIV-1 bNAbs have CDRH3 with an average length of 20.9 amino acids [81]. For example, the CDRH3 of the V2-glycanspecific antibody VRC26-CAP256 is as long as 36 amino acids [46]. Such long HCDR3 of HIV-1 bNAbs indicates major challenges for HIV-1 B cell vaccine development. To overcome this barrier, some novel vaccine strategies have been proposed starting with triggering the germline ancestors followed by boosting various intermediate for the ultimate induction of bNAbs in human [88]. 


\section{Polyreactivity}

Polyreactivity is a common but unusual characteristic of HIV-1 bNAbs that allow promiscuous binding to unrelated self- and/or foreign-antigens with a fairly low affinity. Approximately 55\%-75\% of antibodies produced by early immature B cells in the nascent repertoire exhibit this feature. Polyreactive bNAbs are mostly removed from the system, although approximately 5\% of mature B cells retain the ability to produce such bNAbs [89]. Approximately $70 \%$ of HIV-1 Env-specific antibodies are polyreactive [90]. Therefore, the relatively low frequency of HIV-1 bNAbs in natural infection may be due to the clearance and deletion of poly- and auto-reactive B cell clones.

The exact mechanism for the high polyreactivity in HIV-1 bNAbs is unclear. Evidence suggests that polyreactivity may help increase antibody affinity and avidity for Envs through binding to a second non-HIV-1 antigen on the virion. The density of Env spikes alone is extremely low for the bivalent binding of HIV-1 bNAbs. The estimated density of Env on a mature HIV-1 virion is approximately 14 per virion [91]. For example, MPERspecific antibodies $2 \mathrm{~F} 5$ and $4 \mathrm{E} 10$ bind to gp41 and viral membrane $[29,30]$. Antibody b12 binds to CD4bs and to ribonucleoprotein and double-stranded DNA [17]. Other CD4b antibodies (12A12, NIH45-46, CH103, CH104, and $\mathrm{CH} 106)$ and V1V2 antibodies (CH03) also exhibit varying degrees of polyreactivity [74].

\section{Preferential binding of bNAbs to conformational state 1 of Env}

HIV-1 Env on the surface of virion spontaneously transits through at least three different conformational states: states 1,2 , and $3[92,93]$. All these states are independent of the ligand interaction status with CD4 molecules. After interaction and binding to CD4, a particular bias for a certain state of the Env occurs. State 1 Env predominantly stays in a "closed" conformation that corresponds to the CD4-unbound prefusion state; state 2 is an intermediate state with partially open conformation $[94,95]$. Binding to CD4 and modification of Env residues help drive the Env transitioning into this state [94-97]. State 3 represents an "open" conformation ready for fusion, having been formed and stabilized by CD4 molecules and 17b/co-receptor [94,98].

Recent studies on the dynamics of Env on virion surfaces show that most bNAbs prefer a certain conformational state for binding. For example, many bNAbs favor conformational state 1 over state 2 or 3 of Envs [78,98]. A dynamic study based on single-molecule fluorescence energy transfer (smFRET) reported a preferred Env state for bNAb binding [78], although the exact structural features and their relationship with the recombinant trimeric structures remain unclear. In addition to undergoing spontaneous structural changes on the virion, Env experiences significant structural alterations during HIV-1 entry. Such alterations expose several vulnerable sites on the Env to various antibody-mediated functions, such as neutralization, ADCC, and ADPC [14]. Many human bNAbs bind to CD4 unbound and prefusion-closed Env, indicating that human bNAbs prefer to bind to conformational state $1[78,98]$. The exception to this preference is the bNAb PGT151, which favors Env at states 2 and 3 [78]. The dynamic nature of Env has certainly added another layer of complexity on top of the known sequence and structural diversity of Env. It may also indicate the existence of more vulnerable conformational state where bNAbs could exert effective roles through direct neutralization or an indirect one through ADCC and ADPC.

\section{HIV Env conformational states and immun- ogen design}

\section{Reported dynamics of HIV Env conformational states}

Along with crosslinking/mass spectrometry, X-ray crystallography, and cryo-electron microscopy (cryo-EM), the recently well-developed technique of smFRET offers the unique advantage of defining the conformational structure of HIV-1 Env on the surface of the virion. Furthermore, a novel conformational state named state $2 \mathrm{~A}$ was recently identified, which is largely stabilized by binding to anticluster A antibodies (such as A32 and C11), anti-coreceptor binding site antibodies (such as 17b), and smallmolecule CD4 mimetics (such as BNM-III-170) [99]. State $2 \mathrm{~A}$ is asymmetric and exists when the Env is partially open. State 2A Env mediates ADCC function, whereas state 1 facilitates bNAbs neutralization [78,98,99].

\section{Current updates on HIV conformational states and vaccine candidates}

The existence of bNAbs shows that the natural B cell response can generate protective neutralizing antibodies against HIV-1 infection. Designing an effective vaccine that induces cross-reactive antibodies is of paramont interest in the HIV-1 field. Among the present strategies, the most popular one involves generating a soluble trimeric form of Env to mimic the native Env on the surface of virion. The first and best studied Env trimer is BG505 SOSIP.664, which contains a disulfide bond (SOS), an I559P mutation in gp41 (IP), and a truncation at position 664 to stabilize the trimeric form [100]. Antigenicity studies showed that the BG505 SOSIP.664 trimer displays epitopes that are recognized by bNAbs but not by non- 
bNAbs which closely resemble the conformational structure of the native envelope [100-102]. Additional forms of soluble trimers, such as native flexibly linked (NFL) $[103,104]$ and uncleaved prefusion-optimized (UFO) [105] are also being designed and evaluated. The design of trimer Envs take advantage of the structural information recently obtained through high-resolution X-ray crystallography and cryo-EM [104,106-109]. Many other forms of envelope, such as gp120 monomers, gp120-monomeric core (such as RSC3, 2CC, and 426c core), germlinetargeted proteins (such as eOD-GT proteins), epitopespecific scaffolds (such as FP-KLH), and epitope-based antigenic domain (such as EAD), are also being designed and evaluated as potential immunogens $[70,103,105,110$ 115]. Although each of these immunogens has its own design features and rationale, the ultimate test of their potential as vaccine, that is, their safety, immunogenicity, and protectivity, depends on human studies.

Preliminary results from animals such as mice, guinea pigs, rabbits, and monkeys immunized with SOSIP.664 failed to elicit satisfactory levels of bNAbs against heterologous tier-2 viruses [116-122]. However, the same immunogen can induce broad and potent serum antibody response in cows and dromedaries, suggesting that the long CDRH3 of antibodies in these animals may provide good genetic bases for generating neutralizing antibodies $[123,124]$. Translating the findings in cows and dromedaries into vaccine design for humans remains a challenge. Cow antibodies isolated from immunized animals preferably target the conformational state 2 of Env. Further studies are needed to determine whether this preference is related to the nature of cow antibody triggering virus Env conformation state 2 or whether SOSIP.664 intricately induces state 2-preferred antibodies. If the former case applies, then it is a possibility that the cow antibodies would likely trigger Env into unfavored state. If the latter case applies, then the current SOSIP.664 itself might not be the favored conformation given that most human bNAbs prefer binding to state 1 Env. This scenario may provide some explanations for the failure of SOSIP.664 in eliciting neutralizing antibodies in various animal models. Future vaccine design is needed to consider the conformation states of Env.

\section{Conclusions}

Despite the significant progress in the current understanding of HIV-1 bNAbs, the successful induction of bNAbs-like immune responses in humans remains as a daunting challenge. The biggest challenge is our incomplete understanding of how exactly these bNAbs are generated, evolved, and maintained during infection. A recent study used fusion peptide as immunogen in rhesus macaques has yielded some encouraging results where an antibody lineages can neutralize 59\% of a panel of 208 strains [71]. Hopefully, these discoveries can be translated into human studies in the near future.

\section{Compliance with ethics guidelines}

Qian Wang and Linqi Zhang declare that they have no conflict of interest. This manuscript is a review article and does not involve a research protocol requiring approval by the relevant institutional review board or ethics committee.

Open Access This article is licensed under a Creative Commons Attribution 4.0 International License, which permits use, sharing, adaptation, distribution and reproduction in any medium or format, as long as you give appropriate credit to the original author(s) and the source, provide a link to the Creative Commons licence, and indicate if changes were made.

The images or other third party material in this article are included in the article's Creative Commons licence, unless indicated otherwise in a credit line to the material. If material is not included in the article's Creative Commons licence and your intended use is not permitted by statutory regulation or exceeds the permitted use, you will need to obtain permission directly from the copyright holder.

To view a copy of this licence, visit https://creativecommons.org/ licenses/by/4.0/.

\section{References}

1. Gallo RC, Salahuddin SZ, Popovic M, Shearer GM, Kaplan M, Haynes BF, Palker TJ, Redfield R, Oleske J, Safai B, et al. Frequent detection and isolation of cytopathic retroviruses (HTLVIII) from patients with AIDS and at risk for AIDS. Science 1984; 224(4648): 500-503

2. Barré-Sinoussi F, Chermann JC, Rey F, Nugeyre MT, Chamaret S, Gruest J, Dauguet C, Axler-Blin C, Vézinet-Brun F, Rouzioux C, Rozenbaum W, Montagnier L. Isolation of a T-lymphotropic retrovirus from a patient at risk for acquired immune deficiency syndrome (AIDS). Science 1983; 220(4599): 868-871

3. Baghaei Lakeh A, Ghaffarzadegan N. Global trends and regional variations in studies of HIV/AIDS. Sci Rep 2017; 7(1): 4170

4. UNAIDS. Country factsheets, China 2017. https://www.unaids. org/en/regionscountries/countries/china

5. Hu X, Liang B, Zhou C, Jiang J, Huang J, Ning C, Liu J, Zhou B, Zang N, Lai J, Chen R, Liao Y, Pan P, Liu X, Lan G, Pang X, Ye L, Shen Z, Liang H. HIV late presentation and advanced HIV disease among patients with newly diagnosed HIV/AIDS in Southwestern China: a large-scale cross-sectional study. AIDS Res Ther 2019; 16 (1): 6

6. Buzón MJ, Massanella M, Llibre JM, Esteve A, Dahl V, Puertas MC, Gatell JM, Domingo P, Paredes R, Sharkey M, Palmer S, Stevenson M, Clotet B, Blanco J, Martinez-Picado J. HIV-1 replication and immune dynamics are affected by raltegravir intensification of HAART-suppressed subjects. Nat Med 2010; 16 (4): $460-465$ 
7. Gallo RC. A reflection on HIV/AIDS research after 25 years. Retrovirology 2006; 3(1): 72

8. Siliciano JD, Kajdas J, Finzi D, Quinn TC, Chadwick K, Margolick JB, Kovacs C, Gange SJ, Siliciano RF. Long-term follow-up studies confirm the stability of the latent reservoir for HIV-1 in resting CD4 ${ }^{+}$T cells. Nat Med 2003; 9(6): 727-728

9. Finzi D, Blankson J, Siliciano JD, Margolick JB, Chadwick K, Pierson T, Smith K, Lisziewicz J, Lori F, Flexner C, Quinn TC, Chaisson RE, Rosenberg E, Walker B, Gange S, Gallant J, Siliciano RF. Latent infection of $\mathrm{CD}^{+} \mathrm{T}$ cells provides a mechanism for lifelong persistence of HIV-1, even in patients on effective combination therapy. Nat Med 1999; 5(5): 512-517

10. Gao Y, McKay PF, Mann JFS. Advances in HIV-1 Vaccine Development. Viruses 2018; 10(4): E167

11. Rerks-Ngarm S, Pitisuttithum P, Nitayaphan S, Kaewkungwal J, Chiu J, Paris R, Premsri N, Namwat C, de Souza M, Adams E, Benenson M, Gurunathan S, Tartaglia J, McNeil JG, Francis DP, Stablein D, Birx DL, Chunsuttiwat S, Khamboonruang C, Thongcharoen P, Robb ML, Michael NL, Kunasol P, Kim JH; MOPH-TAVEG Investigators. Vaccination with ALVAC and AIDSVAX to prevent HIV-1 infection in Thailand. N Engl $\mathrm{J}$ Med 2009; 361(23): 2209-2220

12. Excler JL, Robb ML, Kim JH. HIV-1 vaccines: challenges and new perspectives. Hum Vaccin Immunother 2014; 10(6): 1734-1746

13. Kwong PD, Mascola JR. HIV-1 vaccines based on antibody identification, B cell ontogeny, and epitope structure. Immunity 2018; 48(5): 855-871

14. Pancera M, Changela A, Kwong PD. How HIV-1 entry mechanism and broadly neutralizing antibodies guide structure-based vaccine design. Curr Opin HIV AIDS 2017; 12(3): 229-240

15. Landais E, Moore PL. Development of broadly neutralizing antibodies in HIV-1 infected elite neutralizers. Retrovirology 2018; 15(1): 61

16. Mouquet H. Antibody B cell responses in HIV-1 infection. Trends Immunol 2014; 35(11): 549-561

17. Burton DR, Pyati J, Koduri R, Sharp SJ, Thornton GB, Parren PW, Sawyer LS, Hendry RM, Dunlop N, Nara PL, et al. Efficient neutralization of primary isolates of HIV-1 by a recombinant human monoclonal antibody. Science 1994; 266(5187): 10241027

18. Trkola A, Purtscher M, Muster T, Ballaun C, Buchacher A, Sullivan N, Srinivasan K, Sodroski J, Moore JP, Katinger H. Human monoclonal antibody 2G12 defines a distinctive neutralization epitope on the gp120 glycoprotein of human immunodeficiency virus type 1. J Virol 1996; 70(2): 1100-1108

19. Muster T, Steindl F, Purtscher M, Trkola A, Klima A, Himmler G, Rüker F, Katinger H. A conserved neutralizing epitope on gp41 of human immunodeficiency virus type 1. J Virol 1993; 67(11): $6642-6647$

20. Zwick MB, Labrijn AF, Wang M, Spenlehauer C, Saphire EO, Binley JM, Moore JP, Stiegler G, Katinger H, Burton DR, Parren PW. Broadly neutralizing antibodies targeted to the membraneproximal external region of human immunodeficiency virus type 1 glycoprotein gp41. J Virol 2001; 75(22): 10892-10905

21. Saphire EO, Parren PW, Pantophlet R, Zwick MB, Morris GM, Rudd PM, Dwek RA, Stanfield RL, Burton DR, Wilson IA. Crystal structure of a neutralizing human IGG against HIV-1: a template for vaccine design. Science 2001; 293(5532): 1155-1159

22. Mascola JR, Lewis MG, Stiegler G, Harris D, VanCott TC, Hayes D, Louder MK, Brown CR, Sapan CV, Frankel SS, Lu Y, Robb ML, Katinger H, Birx DL. Protection of macaques against pathogenic simian/human immunodeficiency virus $89.6 \mathrm{PD}$ by passive transfer of neutralizing antibodies. J Virol 1999; 73(5): 4009-4018

23. Mascola JR, Stiegler G, VanCott TC, Katinger H, Carpenter CB, Hanson CE, Beary H, Hayes D, Frankel SS, Birx DL, Lewis MG. Protection of macaques against vaginal transmission of a pathogenic HIV-1/SIV chimeric virus by passive infusion of neutralizing antibodies. Nat Med 2000; 6(2): 207-210

24. Baba TW, Liska V, Hofmann-Lehmann R, Vlasak J, Xu W, Ayehunie S, Cavacini LA, Posner MR, Katinger H, Stiegler G, Bernacky BJ, Rizvi TA, Schmidt R, Hill LR, Keeling ME, Lu Y, Wright JE, Chou TC, Ruprecht RM. Human neutralizing monoclonal antibodies of the IgG1 subtype protect against mucosal simian-human immunodeficiency virus infection. Nat Med 2000; 6(2): 200-206

25. Hessell AJ, Poignard P, Hunter M, Hangartner L, Tehrani DM, Bleeker WK, Parren PW, Marx PA, Burton DR. Effective, low-titer antibody protection against low-dose repeated mucosal SHIV challenge in macaques. Nat Med 2009; 15(8): 951-954

26. Hessell AJ, Rakasz EG, Poignard P, Hangartner L, Landucci G, Forthal DN, Koff WC, Watkins DI, Burton DR. Broadly neutralizing human anti-HIV antibody $2 \mathrm{G} 12$ is effective in protection against mucosal SHIV challenge even at low serum neutralizing titers. PLoS Pathog 2009; 5(5): e1000433

27. Hessell AJ, Rakasz EG, Tehrani DM, Huber M, Weisgrau KL, Landucci G, Forthal DN, Koff WC, Poignard P, Watkins DI, Burton DR. Broadly neutralizing monoclonal antibodies 2F5 and 4E10 directed against the human immunodeficiency virus type 1 gp41 membrane-proximal external region protect against mucosal challenge by simian-human immunodeficiency virus SHIVBa-L. J Virol 2010; 84(3): 1302-1313

28. Calarese DA, Scanlan CN, Zwick MB, Deechongkit S, Mimura Y, Kunert R, Zhu P, Wormald MR, Stanfield RL, Roux KH, Kelly JW, Rudd PM, Dwek RA, Katinger H, Burton DR, Wilson IA. Antibody domain exchange is an immunological solution to carbohydrate cluster recognition. Science 2003; 300(5628): 20652071

29. Yang G, Holl TM, Liu Y, Li Y, Lu X, Nicely NI, Kepler TB, Alam SM, Liao HX, Cain DW, Spicer L, VandeBerg JL, Haynes BF, Kelsoe G. Identification of autoantigens recognized by the $2 \mathrm{~F} 5$ and 4E10 broadly neutralizing HIV-1 antibodies. J Exp Med 2013; 210 (2): 241-256

30. Haynes BF, Fleming J, St Clair EW, Katinger H, Stiegler G, Kunert R, Robinson J, Scearce RM, Plonk K, Staats HF, Ortel TL, Liao HX, Alam SM. Cardiolipin polyspecific autoreactivity in two broadly neutralizing HIV-1 antibodies. Science 2005; 308(5730): 1906-1908

31. Gruell H, Klein F. Antibody-mediated prevention and treatment of HIV-1 infection. Retrovirology 2018; 15(1): 73

32. Doria-Rose NA, Klein RM, Manion MM, O’Dell S, Phogat A, Chakrabarti B, Hallahan CW, Migueles SA, Wrammert J, Ahmed R, Nason M, Wyatt RT, Mascola JR, Connors M. Frequency and phenotype of human immunodeficiency virus envelope-specific $\mathrm{B}$ cells from patients with broadly cross-neutralizing antibodies. $\mathrm{J}$ 
Virol 2009; 83(1): 188-199

33. Mikell I, Sather DN, Kalams SA, Altfeld M, Alter G, Stamatatos L. Characteristics of the earliest cross-neutralizing antibody response to HIV-1. PLoS Pathog 2011; 7(1): e1001251

34. Gray ES, Madiga MC, Hermanus T, Moore PL, Wibmer CK, Tumba NL, Werner L, Mlisana K, Sibeko S, Williamson C, Abdool Karim SS, Morris L; CAPRISA002 Study Team. The neutralization breadth of HIV-1 develops incrementally over four years and is associated with $\mathrm{CD} 4^{+} \mathrm{T}$ cell decline and high viral load during acute infection. J Virol 2011; 85(10): 4828-4840

35. Stamatatos L, Morris L, Burton DR, Mascola JR. Neutralizing antibodies generated during natural HIV-1 infection: good news for an HIV-1 vaccine? Nat Med 2009; 15(8): 866-870

36. Sather DN, Armann J, Ching LK, Mavrantoni A, Sellhorn G, Caldwell Z, Yu X, Wood B, Self S, Kalams S, Stamatatos L. Factors associated with the development of cross-reactive neutralizing antibodies during human immunodeficiency virus type 1 infection. J Virol 2009; 83(2): 757-769

37. Doria-Rose NA, Klein RM, Daniels MG, O’Dell S, Nason M, Lapedes A, Bhattacharya T, Migueles SA, Wyatt RT, Korber BT, Mascola JR, Connors M. Breadth of human immunodeficiency virus-specific neutralizing activity in sera: clustering analysis and association with clinical variables. J Virol 2010; 84(3): 1631-1636

38. AVAC. HIV-specific neutralizing antibodies - targets and research status 2019. https://www.avac.org/infographic/hiv-specific-neutralizing-antibodies-targets-and-research-status

39. AVAC. Broadly neutralizing antibody combinations 2019. https:// www.avac.org/infographic/bnab-combinations

40. McLellan JS, Pancera M, Carrico C, Gorman J, Julien JP, Khayat R, Louder R, Pejchal R, Sastry M, Dai K, O'Dell S, Patel N, Shahzad-ul-Hussan S, Yang Y, Zhang B, Zhou T, Zhu J, Boyington JC, Chuang GY, Diwanji D, Georgiev I, Kwon YD, Lee D, Louder MK, Moquin S, Schmidt SD, Yang ZY, Bonsignori M, Crump JA, Kapiga SH, Sam NE, Haynes BF, Burton DR, Koff WC, Walker LM, Phogat S, Wyatt R, Orwenyo J, Wang LX, Arthos J, Bewley CA, Mascola JR, Nabel GJ, Schief WR, Ward AB, Wilson IA, Kwong PD. Structure of HIV-1 gp120 V1/V2 domain with broadly neutralizing antibody PG9. Nature 2011; 480 (7377): 336-343

41. Julien JP, Lee JH, Cupo A, Murin CD, Derking R, Hoffenberg S, Caulfield MJ, King CR, Marozsan AJ, Klasse PJ, Sanders RW, Moore JP, Wilson IA, Ward AB. Asymmetric recognition of the HIV-1 trimer by broadly neutralizing antibody PG9. Proc Natl Acad Sci USA 2013; 110(11): 4351-4356

42. Walker LM, Phogat SK, Chan-Hui PY, Wagner D, Phung P, Goss JL, Wrin T, Simek MD, Fling S, Mitcham JL, Lehrman JK, Priddy FH, Olsen OA, Frey SM, Hammond PW; Protocol G Principal Investigators, Kaminsky S, Zamb T, Moyle M, Koff WC, Poignard $\mathrm{P}$, Burton DR, Burton DR. Broad and potent neutralizing antibodies from an African donor reveal a new HIV-1 vaccine target. Science 2009; 326(5950): 285-289

43. Bonsignori M, Hwang KK, Chen X, Tsao CY, Morris L, Gray E, Marshall DJ, Crump JA, Kapiga SH, Sam NE, Sinangil F, Pancera M, Yongping Y, Zhang B, Zhu J, Kwong PD, O’Dell S, Mascola JR, Wu L, Nabel GJ, Phogat S, Seaman MS, Whitesides JF, Moody MA, Kelsoe G, Yang X, Sodroski J, Shaw GM, Montefiori DC, Kepler TB, Tomaras GD, Alam SM, Liao HX, Haynes BF. Analysis of a clonal lineage of HIV-1 envelope V2/V3 conforma- tional epitope-specific broadly neutralizing antibodies and their inferred unmutated common ancestors. J Virol 2011; 85(19): 9998-10009

44. Walker LM, Huber M, Doores KJ, Falkowska E, Pejchal R, Julien JP, Wang SK, Ramos A, Chan-Hui PY, Moyle M, Mitcham JL, Hammond PW, Olsen OA, Phung P, Fling S, Wong CH, Phogat S, Wrin T, Simek MD; Protocol G Principal Investigators, Koff WC, Wilson IA, Burton DR, Poignard P, Poignard P. Broad neutralization coverage of HIV by multiple highly potent antibodies. Nature 2011; 477(7365): 466-470

45. Sok D, van Gils MJ, Pauthner M, Julien JP, Saye-Francisco KL, Hsueh J, Briney B, Lee JH, Le KM, Lee PS, Hua Y, Seaman MS, Moore JP, Ward AB, Wilson IA, Sanders RW, Burton DR. Recombinant HIV envelope trimer selects for quaternary-dependent antibodies targeting the trimer apex. Proc Natl Acad Sci USA 2014; 111(49): 17624-17629

46. Doria-Rose NA, Schramm CA, Gorman J, Moore PL, Bhiman JN, DeKosky BJ, Ernandes MJ, Georgiev IS, Kim HJ, Pancera M, Staupe RP, Altae-Tran HR, Bailer RT, Crooks ET, Cupo A, Druz A, Garrett NJ, Hoi KH, Kong R, Louder MK, Longo NS, McKee K, Nonyane M, O'Dell S, Roark RS, Rudicell RS, Schmidt SD, Sheward DJ, Soto C, Wibmer CK, Yang Y, Zhang Z; NISC Comparative Sequencing Program, Mullikin JC, Binley JM, Sanders RW, Wilson IA, Moore JP, Ward AB, Georgiou G, Williamson C, Abdool Karim SS, Morris L, Kwong PD, Shapiro L, Mascola JR. Developmental pathway for potent V1V2-directed HIV-neutralizing antibodies. Nature 2014; 509(7498): 55-62

47. Mouquet H, Scharf L, Euler Z, Liu Y, Eden C, Scheid JF, HalperStromberg A, Gnanapragasam PN, Spencer DI, Seaman MS, Schuitemaker H, Feizi T, Nussenzweig MC, Bjorkman PJ. Complex-type $\mathrm{N}$-glycan recognition by potent broadly neutralizing HIV antibodies. Proc Natl Acad Sci USA 2012; 109(47): E3268E3277

48. Julien JP, Sok D, Khayat R, Lee JH, Doores KJ, Walker LM, Ramos A, Diwanji DC, Pejchal R, Cupo A, Katpally U, Depetris RS, Stanfield RL, McBride R, Marozsan AJ, Paulson JC, Sanders RW, Moore JP, Burton DR, Poignard P, Ward AB, Wilson IA. Broadly neutralizing antibody PGT121 allosterically modulates CD4 binding via recognition of the HIV-1 gp120 V3 base and multiple surrounding glycans. PLoS Pathog 2013; 9(5): e1003342

49. Pejchal R, Doores KJ, Walker LM, Khayat R, Huang PS, Wang SK, Stanfield RL, Julien JP, Ramos A, Crispin M, Depetris R, Katpally U, Marozsan A, Cupo A, Maloveste S, Liu Y, McBride R, Ito Y, Sanders RW, Ogohara C, Paulson JC, Feizi T, Scanlan CN, Wong CH, Moore JP, Olson WC, Ward AB, Poignard P, Schief WR, Burton DR, Wilson IA. A potent and broad neutralizing antibody recognizes and penetrates the HIV glycan shield. Science 2011; 334(6059): 1097-1103

50. Sok D, Pauthner M, Briney B, Lee JH, Saye-Francisco KL, Hsueh J, Ramos A, Le KM, Jones M, Jardine JG, Bastidas R, Sarkar A, Liang $\mathrm{CH}$, Shivatare SS, Wu CY, Schief WR, Wong CH, Wilson IA, Ward AB, Zhu J, Poignard P, Burton DR. A prominent site of antibody vulnerability on HIV envelope incorporates a motif associated with CCR5 binding and its camouflaging glycans. Immunity 2016; 45(1): 31-45

51. Dalgleish AG, Beverley PC, Clapham PR, Crawford DH, Greaves MF, Weiss RA. The CD4 (T4) antigen is an essential component of the receptor for the AIDS retrovirus. Nature 1984; 312(5996): 763- 
767

52. Klatzmann D, Champagne E, Chamaret S, Gruest J, Guetard D, Hercend T, Gluckman JC, Montagnier L. T-lymphocyte T4 molecule behaves as the receptor for human retrovirus LAV. Nature 1984; 312(5996): 767-768

53. Zhou T, Xu L, Dey B, Hessell AJ, van Ryk D, Xiang SH, Yang X, Zhang MY, Zwick MB, Arthos J, Burton DR, Dimitrov DS, Sodroski J, Wyatt R, Nabel GJ, Kwong PD. Structural definition of a conserved neutralization epitope on HIV-1 gp120. Nature 2007; 445(7129): 732-737

54. Zhou T, Lynch RM, Chen L, Acharya P, Wu X, Doria-Rose NA, Joyce MG, Lingwood D, Soto C, Bailer RT, Ernandes MJ, Kong R, Longo NS, Louder MK, McKee K, O’Dell S, Schmidt SD, Tran L, Yang Z, Druz A, Luongo TS, Moquin S, Srivatsan S, Yang Y, Zhang B, Zheng A, Pancera M, Kirys T, Georgiev IS, Gindin T, Peng HP, Yang AS; NISC Comparative Sequencing Program, Mullikin JC, Gray MD, Stamatatos L, Burton DR, Koff WC, Cohen MS, Haynes BF, Casazza JP, Connors M, Corti D, Lanzavecchia A, Sattentau QJ, Weiss RA, West AP Jr, Bjorkman PJ, Scheid JF, Nussenzweig MC, Shapiro L, Mascola JR, Kwong PD, Kwong PD. Structural repertoire of HIV-1-neutralizing antibodies targeting the CD4 supersite in 14 donors. Cell 2015; 161(6): 1280-1292

55. Sajadi MM, Dashti A, Rikhtegaran Tehrani Z, Tolbert WD, Seaman MS, Ouyang X, Gohain N, Pazgier M, Kim D, Cavet G, Yared J, Redfield RR, Lewis GK, DeVico AL. Identification of near-Pan-neutralizing antibodies against HIV-1 by deconvolution of plasma humoral responses. Cell 2018; 173(7): 1783-1795.e14

56. Wu X, Yang ZY, Li Y, Hogerkorp CM, Schief WR, Seaman MS, Zhou T, Schmidt SD, Wu L, Xu L, Longo NS, McKee K, O’Dell S, Louder MK, Wycuff DL, Feng Y, Nason M, Doria-Rose N, Connors M, Kwong PD, Roederer M, Wyatt RT, Nabel GJ, Mascola JR. Rational design of envelope identifies broadly neutralizing human monoclonal antibodies to HIV-1. Science 2010; 329(5993): 856-861

57. Huang J, Kang BH, Ishida E, Zhou T, Griesman T, Sheng Z, Wu F, Doria-Rose NA, Zhang B, McKee K, O’Dell S, Chuang GY, Druz A, Georgiev IS, Schramm CA, Zheng A, Joyce MG, Asokan M, Ransier A, Darko S, Migueles SA, Bailer RT, Louder MK, Alam SM, Parks R, Kelsoe G, Von Holle T, Haynes BF, Douek DC, Hirsch V, Seaman MS, Shapiro L, Mascola JR, Kwong PD, Connors M. Identification of a CD4-binding-site antibody to HIV that evolved near-Pan neutralization breadth. Immunity 2016; 45 (5): 1108-1121

58. Rudicell RS, Kwon YD, Ko SY, Pegu A, Louder MK, Georgiev IS, Wu X, Zhu J, Boyington JC, Chen X, Shi W, Yang ZY, DoriaRose NA, McKee K, O’Dell S, Schmidt SD, Chuang GY, Druz A, Soto C, Yang Y, Zhang B, Zhou T, Todd JP, Lloyd KE, Eudailey J, Roberts KE, Donald BR, Bailer RT, Ledgerwood J; NISC Comparative Sequencing Program, Mullikin JC, Shapiro L, Koup RA, Graham BS, Nason MC, Connors M, Haynes BF, Rao SS, Roederer M, Kwong PD, Mascola JR, Nabel GJ, Nabel GJ. Enhanced potency of a broadly neutralizing HIV-1 antibody in vitro improves protection against lentiviral infection in vivo. J Virol 2014; 88(21): 12669-12682

59. Scheid JF, Mouquet H, Ueberheide B, Diskin R, Klein F, Oliveira TY, Pietzsch J, Fenyo D, Abadir A, Velinzon K, Hurley A, Myung S, Boulad F, Poignard P, Burton DR, Pereyra F, Ho DD, Walker
BD, Seaman MS, Bjorkman PJ, Chait BT, Nussenzweig MC. Sequence and structural convergence of broad and potent HIV antibodies that mimic CD4 binding. Science 2011; 333(6049): 1633-1637

60. Zhou P, Wang H, Fang M, Li Y, Wang H, Shi S, Li Z, Wu J, Han X, Shi X, Shang H, Zhou T, Zhang L. Broadly resistant HIV-1 against CD4-binding site neutralizing antibodies. PLoS Pathog 2019; 15 (6): e1007819

61. Huang J, Ofek G, Laub L, Louder MK, Doria-Rose NA, Longo NS, Imamichi H, Bailer RT, Chakrabarti B, Sharma SK, Alam SM, Wang T, Yang Y, Zhang B, Migueles SA, Wyatt R, Haynes BF, Kwong PD, Mascola JR, Connors M. Broad and potent neutralization of HIV-1 by a gp41-specific human antibody. Nature 2012; 491(7424): 406-412

62. Krebs SJ, Kwon YD, Schramm CA, Law WH, Donofrio G, Zhou KH, Gift S, Dussupt V, Georgiev IS, Schatzle S, McDaniel JR, Lai YT, Sastry M, Zhang B, Jarosinski MC, Ransier A, Chenine AL, Asokan M, Bailer RT, Bose M, Cagigi A, Cale EM, Chuang GY, Darko S, Driscoll JI, Druz A, Gorman J, Laboune F, Louder MK, McKee K, Mendez L, Moody MA, O'Sullivan AM, Owen C, Peng D, Rawi R, Sanders-Buell E, Shen CH, Shiakolas AR, Stephens T, Tsybovsky Y, Tucker C, Verardi R, Wang K, Zhou J, Zhou T, Georgiou G, Alam SM, Haynes BF, Rolland M, Matyas GR, Polonis VR, McDermott AB, Douek DC, Shapiro L, Tovanabutra S, Michael NL, Mascola JR, Robb ML, Kwong PD, Doria-Rose NA. Longitudinal analysis reveals early development of three MPER-directed neutralizing antibody lineages from an HIV-1infected individual. Immunity 2019; 50(3): 677-691.e13

63. Huang J, Kang BH, Pancera M, Lee JH, Tong T, Feng Y, Imamichi H, Georgiev IS, Chuang GY, Druz A, Doria-Rose NA, Laub L, Sliepen K, van Gils MJ, de la Peña AT, Derking R, Klasse PJ, Migueles SA, Bailer RT, Alam M, Pugach P, Haynes BF, Wyatt RT, Sanders RW, Binley JM, Ward AB, Mascola JR, Kwong PD, Connors M. Broad and potent HIV-1 neutralization by a human antibody that binds the gp41-gp120 interface. Nature 2014; 515 (7525): 138-142

64. Scharf L, Scheid JF, Lee JH, West AP Jr, Chen C, Gao H, Gnanapragasam PN, Mares R, Seaman MS, Ward AB, Nussenzweig MC, Bjorkman PJ. Antibody 8ANC195 reveals a site of broad vulnerability on the HIV-1 envelope spike. Cell Reports 2014; 7(3): 785-795

65. Scharf L, Wang H, Gao H, Chen S, McDowall AW, Bjorkman PJ. Broadly neutralizing antibody 8ANC195 recognizes closed and open states of HIV-1 Env. Cell 2015; 162(6): 1379-1390

66. Kong R, Xu K, Zhou T, Acharya P, Lemmin T, Liu K, Ozorowski G, Soto C, Taft JD, Bailer RT, Cale EM, Chen L, Choi CW, Chuang GY, Doria-Rose NA, Druz A, Georgiev IS, Gorman J, Huang J, Joyce MG, Louder MK, Ma X, McKee K, O’Dell S, Pancera M, Yang Y, Blanchard SC, Mothes W, Burton DR, Koff WC, Connors M, Ward AB, Kwong PD, Mascola JR. Fusion peptide of HIV-1 as a site of vulnerability to neutralizing antibody. Science 2016; 352(6287): 828-833

67. Falkowska E, Le KM, Ramos A, Doores KJ, Lee JH, Blattner C, Ramirez A, Derking R, van Gils MJ, Liang CH, Mcbride R, von Bredow B, Shivatare SS, Wu CY, Chan-Hui PY, Liu Y, Feizi T, Zwick MB, Koff WC, Seaman MS, Swiderek K, Moore JP, Evans D, Paulson JC, Wong CH, Ward AB, Wilson IA, Sanders RW, Poignard P, Burton DR. Broadly neutralizing HIV antibodies 
define a glycan-dependent epitope on the prefusion conformation of gp41 on cleaved envelope trimers. Immunity 2014; 40(5): 657 668

68. van Gils MJ, van den Kerkhof TLGM, Ozorowski G, Cottrell CA, Sok D, Pauthner M, Pallesen J, de Val N, Yasmeen A, de Taeye SW, Schorcht A, Gumbs S, Johanna I, Saye-Francisco K, Liang CH, Landais E, Nie X, Pritchard LK, Crispin M, Kelsoe G, Wilson IA, Schuitemaker H, Klasse PJ, Moore JP, Burton DR, Ward AB, Sanders RW. An HIV-1 antibody from an elite neutralizer implicates the fusion peptide as a site of vulnerability. Nat Microbiol 2016; 2(2): 16199

69. Yuan M, Cottrell CA, Ozorowski G, van Gils MJ, Kumar S, Wu NC, Sarkar A, Torres JL, de Val N, Copps J, Moore JP, Sanders RW, Ward AB, Wilson IA. Conformational plasticity in the HIV-1 fusion peptide facilitates recognition by broadly neutralizing antibodies. Cell Host Microbe 2019; 25(6): 873-883.e5

70. Xu K, Acharya P, Kong R, Cheng C, Chuang GY, Liu K, Louder MK, O’Dell S, Rawi R, Sastry M, Shen CH, Zhang B, Zhou T, Asokan M, Bailer RT, Chambers M, Chen X, Choi CW, Dandey VP, Doria-Rose NA, Druz A, Eng ET, Farney SK, Foulds KE, Geng H, Georgiev IS, Gorman J, Hill KR, Jafari AJ, Kwon YD, Lai YT, Lemmin T, McKee K, Ohr TY, Ou L, Peng D, Rowshan AP, Sheng Z, Todd JP, Tsybovsky Y, Viox EG, Wang Y, Wei H, Yang Y, Zhou AF, Chen R, Yang L, Scorpio DG, McDermott AB, Shapiro L, Carragher B, Potter CS, Mascola JR, Kwong PD. Epitope-based vaccine design yields fusion peptide-directed antibodies that neutralize diverse strains of HIV-1. Nat Med 2018; 24(6): 857-867

71. Kong R, Duan H, Sheng Z, Xu K, Acharya P, Chen X, Cheng C, Dingens AS, Gorman J, Sastry M, Shen CH, Zhang B, Zhou T, Chuang GY, Chao CW, Gu Y, Jafari AJ, Louder MK, O'Dell S, Rowshan AP, Viox EG, Wang Y, Choi CW, Corcoran MM, Corrigan AR, Dandey VP, Eng ET, Geng H, Foulds KE, Guo Y, Kwon YD, Lin B, Liu K, Mason RD, Nason MC, Ohr TY, Ou L, Rawi R, Sarfo EK, Schon A, Todd JP, Wang S, Wei H, Wu W, Program NCS, Mullikin JC, Bailer RT, Doria-Rose NA, Karlsson Hedestam GB, Scorpio DG, Overbaugh J, Bloom JD, Carragher B, Potter CS, Shapiro L, Kwong PD, Mascola JR. Antibody lineages with vaccine-induced antigen-binding hotspots develop broad HIV neutralization. Cell 2019; 178(3): 567-584.e19

72. Zhou T, Zheng A, Baxa U, Chuang GY, Georgiev IS, Kong R, O’Dell S, Shahzad-Ul-Hussan S, Shen CH, Tsybovsky Y, Bailer RT, Gift SK, Louder MK, McKee K, Rawi R, Stevenson CH, Stewart-Jones GBE, Taft JD, Waltari E, Yang Y, Zhang B, Shivatare SS, Shivatare VS, Lee CD, Wu CY, Program NCS, Mullikin JC, Bewley CA, Burton DR, Polonis VR, Shapiro L, Wong $\mathrm{CH}$, Mascola JR, Kwong PD, Wu X. A neutralizing antibody recognizing primarily $\mathrm{N}$-linked glycan targets the silent face of the HIV envelope. Immunity 2018; 48(3): 500-513.e6

73. Schoofs T, Barnes CO, Suh-Toma N, Golijanin J, Schommers P, Gruell H, West AP, Jr., Bach F, Lee YE, Nogueira L, Georgiev IS, Bailer RT, Czartoski J, Mascola JR, Seaman MS, McElrath MJ, Doria-Rose NA, Klein F, Nussenzweig MC, Bjorkman PJ. Broad and potent neutralizing antibodies recognize the silent face of the HIV envelope. Immunity 2019; 50(6): 1513-1529.e9

74. Mascola JR, Haynes BF. HIV-1 neutralizing antibodies: understanding nature's pathways. Immunol Rev 2013; 254(1): 225244
75. Klein F, Mouquet H, Dosenovic P, Scheid JF, Scharf L, Nussenzweig MC. Antibodies in HIV-1 vaccine development and therapy. Science 2013; 341(6151): 1199-1204

76. Wu X, Zhou T, Zhu J, Zhang B, Georgiev I, Wang C, Chen X, Longo NS, Louder M, McKee K, O'Dell S, Perfetto S, Schmidt SD, Shi W, Wu L, Yang Y, Yang ZY, Yang Z, Zhang Z, Bonsignori M, Crump JA, Kapiga SH, Sam NE, Haynes BF, Simek M, Burton DR, Koff WC, Doria-Rose NA, Connors M; NISC Comparative Sequencing Program, Mullikin JC, Nabel GJ, Roederer M, Shapiro L, Kwong PD, Mascola JR, Mascola JR. Focused evolution of HIV-1 neutralizing antibodies revealed by structures and deep sequencing. Science 2011; 333(6049): 1593-1602

77. Liao HX, Lynch R, Zhou T, Gao F, Alam SM, Boyd SD, Fire AZ, Roskin KM, Schramm CA, Zhang Z, Zhu J, Shapiro L; NISC Comparative Sequencing Program, Mullikin JC, Gnanakaran S, Hraber P, Wiehe K, Kelsoe G, Yang G, Xia SM, Montefiori DC, Parks R, Lloyd KE, Scearce RM, Soderberg KA, Cohen M, Kamanga G, Louder MK, Tran LM, Chen Y, Cai F, Chen S, Moquin S, Du X, Joyce MG, Srivatsan S, Zhang B, Zheng A, Shaw GM, Hahn BH, Kepler TB, Korber BT, Kwong PD, Mascola JR, Haynes BF, Haynes BF. Co-evolution of a broadly neutralizing HIV-1 antibody and founder virus. Nature 2013; 496(7446): 469 476

78. Lu M, Ma X, Castillo-Menendez LR, Gorman J, Alsahafi N, Ermel U, Terry DS, Chambers M, Peng D, Zhang B, Zhou T, Reichard N, Wang K, Grover JR, Carman BP, Gardner MR, Nikić-Spiegel I, Sugawara A, Arthos J, Lemke EA, Smith AB 3rd, Farzan M, Abrams C, Munro JB, McDermott AB, Finzi A, Kwong PD, Blanchard SC, Sodroski JG, Mothes W. Associating HIV-1 envelope glycoprotein structures with states on the virus observed by smFRET. Nature 2019; 568(7752): 415-419

79. Cohen MS, Shaw GM, McMichael AJ, Haynes BF. Acute HIV-1 infection. N Engl J Med 2011; 364(20): 1943-1954

80. McMichael AJ, Borrow P, Tomaras GD, Goonetilleke N, Haynes BF. The immune response during acute HIV-1 infection: clues for vaccine development. Nat Rev Immunol 2010; 10(1): 11-23

81. Breden F, Lepik C, Longo NS, Montero M, Lipsky PE, Scott JK. Comparison of antibody repertoires produced by HIV-1 infection, other chronic and acute infections, and systemic autoimmune disease. PLoS One 2011; 6(3): e16857

82. Scheid JF, Mouquet H, Feldhahn N, Seaman MS, Velinzon K, Pietzsch J, Ott RG, Anthony RM, Zebroski H, Hurley A, Phogat A, Chakrabarti B, Li Y, Connors M, Pereyra F, Walker BD, Wardemann H, Ho D, Wyatt RT, Mascola JR, Ravetch JV, Nussenzweig MC. Broad diversity of neutralizing antibodies isolated from memory B cells in HIV-infected individuals. Nature 2009; 458(7238): 636-640

83. Tiller T, Tsuiji M, Yurasov S, Velinzon K, Nussenzweig MC, Wardemann $\mathrm{H}$. Autoreactivity in human $\mathrm{IgG}^{+}$memory B cells. Immunity 2007; 26(2): 205-213

84. Klein F, Diskin R, Scheid JF, Gaebler C, Mouquet H, Georgiev IS, Pancera M, Zhou T, Incesu RB, Fu BZ, Gnanapragasam PN, Oliveira TY, Seaman MS, Kwong PD, Bjorkman PJ, Nussenzweig MC. Somatic mutations of the immunoglobulin framework are generally required for broad and potent HIV-1 neutralization. Cell 2013; 153(1): 126-138

85. Kepler TB, Liao HX, Alam SM, Bhaskarabhatla R, Zhang R, Yandava C, Stewart S, Anasti K, Kelsoe G, Parks R, Lloyd KE, 
Stolarchuk C, Pritchett J, Solomon E, Friberg E, Morris L, Karim SS, Cohen MS, Walter E, Moody MA, Wu X, Altae-Tran HR, Georgiev IS, Kwong PD, Boyd SD, Fire AZ, Mascola JR, Haynes $\mathrm{BF}$. Immunoglobulin gene insertions and deletions in the affinity maturation of HIV-1 broadly reactive neutralizing antibodies. Cell Host Microbe 2014; 16(3): 304-313

86. Xiao X, Chen W, Feng Y, Zhu Z, Prabakaran P, Wang Y, Zhang MY, Longo NS, Dimitrov DS. Germline-like predecessors of broadly neutralizing antibodies lack measurable binding to HIV-1 envelope glycoproteins: implications for evasion of immune responses and design of vaccine immunogens. Biochem Biophys Res Commun 2009; 390(3): 404-409

87. Liao HX, Chen X, Munshaw S, Zhang R, Marshall DJ, Vandergrift N, Whitesides JF, Lu X, Yu JS, Hwang KK, Gao F, Markowitz M, Heath SL, Bar KJ, Goepfert PA, Montefiori DC, Shaw GC, Alam SM, Margolis DM, Denny TN, Boyd SD, Marshal E, Egholm M, Simen BB, Hanczaruk B, Fire AZ, Voss G, Kelsoe G, Tomaras GD, Moody MA, Kepler TB, Haynes BF. Initial antibodies binding to HIV-1 gp41 in acutely infected subjects are polyreactive and highly mutated. J Exp Med 2011; 208(11): 2237-2249

88. Flemming A. HIV: sequential vaccine elicits broadly neutralizing antibodies. Nat Rev Drug Discov 2016; 15(11): 748-749

89. Wardemann H, Yurasov S, Schaefer A, Young JW, Meffre E, Nussenzweig MC. Predominant autoantibody production by early human B cell precursors. Science 2003; 301(5638): 1374-1377

90. Mouquet H, Scheid JF, Zoller MJ, Krogsgaard M, Ott RG, Shukair S, Artyomov MN, Pietzsch J, Connors M, Pereyra F, Walker BD, Ho DD, Wilson PC, Seaman MS, Eisen HN, Chakraborty AK, Hope TJ, Ravetch JV, Wardemann H, Nussenzweig MC. Polyreactivity increases the apparent affinity of anti-HIV antibodies by heteroligation. Nature 2010; 467(7315): 591-595

91. Zhu P, Liu J, Bess J Jr, Chertova E, Lifson JD, Grisé H, Ofek GA, Taylor KA, Roux KH. Distribution and three-dimensional structure of AIDS virus envelope spikes. Nature 2006; 441(7095): 847852

92. Herschhorn A, Sodroski J. An entry-competent intermediate state of the HIV-1 envelope glycoproteins. Receptors Clin Investig 2017; 4(1): e1544

93. Bruel T, Schwartz O. HIV-1 envelope FRETted over by antibodies. Cell Host Microbe 2019; 25(6): 767-768

94. Ma X, Lu M, Gorman J, Terry DS, Hong X, Zhou Z, Zhao H, Altman RB, Arthos J, Blanchard SC, Kwong PD, Munro JB, Mothes W. HIV-1 Env trimer opens through an asymmetric intermediate in which individual protomers adopt distinct conformations. eLife 2018; 7:e34271

95. Herschhorn A, Ma X, Gu C, Ventura JD, Castillo-Menendez L, Melillo B, Terry DS, Smith AB 3rd, Blanchard SC, Munro JB, Mothes W, Finzi A, Sodroski J. Release of gp120 restraints leads to an entry-competent intermediate state of the HIV-1 envelope glycoproteins. MBio 2016; 7(5): e01598-16

96. Herschhorn A, Gu C, Moraca F, Ma X, Farrell M, Smith AB 3rd, Pancera M, Kwong PD, Schön A, Freire E, Abrams C, Blanchard $\mathrm{SC}$, Mothes W, Sodroski JG. The $\beta 20-\beta 21$ of gp120 is a regulatory switch for HIV-1 Env conformational transitions. Nat Commun 2017; 8(1): 1049

97. Wang Q, Liu L, Ren W, Gettie A, Wang H, Liang Q, Shi X, Montefiori DC, Zhou T, Zhang L. A single substitution in gp41 modulates the neutralization profile of SHIV during in vivo adaptation. Cell Reports 2019; 27(9): 2593-2607.e5

98. Munro JB, Gorman J, Ma X, Zhou Z, Arthos J, Burton DR, Koff WC, Courter JR, Smith AB 3rd, Kwong PD, Blanchard SC, Mothes W. Conformational dynamics of single HIV-1 envelope trimers on the surface of native virions. Science 2014; 346(6210): 759-763

99. Alsahafi N, Bakouche N, Kazemi M, Richard J, Ding S, Bhattacharyya S, Das D, Anand SP, Prevost J, Tolbert WD, Lu H, Medjahed H, Gendron-Lepage G, Ortega Delgado GG, Kirk S, Melillo B, Mothes W, Sodroski J, Smith AB, 3rd, Kaufmann DE, Wu X, Pazgier M, Rouiller I, Finzi A, Munro JB. An asymmetric opening of HIV-1 envelope mediates antibody-dependent cellular cytotoxicity. Cell Host Microbe 2019; 25(4): 578-587.e5

100. Sanders RW, Derking R, Cupo A, Julien JP, Yasmeen A, de Val N, Kim HJ, Blattner C, de la Peña AT, Korzun J, Golabek M, de Los Reyes K, Ketas TJ, van Gils MJ, King CR, Wilson IA, Ward AB, Klasse PJ, Moore JP. A next-generation cleaved, soluble HIV-1 Env trimer, BG505 SOSIP.664 gp140, expresses multiple epitopes for broadly neutralizing but not non-neutralizing antibodies. PLoS Pathog 2013; 9(9): e1003618

101. Kwon YD, Pancera M, Acharya P, Georgiev IS, Crooks ET, Gorman J, Joyce MG, Guttman M, Ma X, Narpala S, Soto C, Terry DS, Yang Y, Zhou T, Ahlsen G, Bailer RT, Chambers M, Chuang GY, Doria-Rose NA, Druz A, Hallen MA, Harned A, Kirys T, Louder MK, O’Dell S, Ofek G, Osawa K, Prabhakaran M, Sastry M, Stewart-Jones GB, Stuckey J, Thomas PV, Tittley T, Williams C, Zhang B, Zhao H, Zhou Z, Donald BR, Lee LK, Zolla-Pazner S, Baxa U, Schön A, Freire E, Shapiro L, Lee KK, Arthos J, Munro JB, Blanchard SC, Mothes W, Binley JM, McDermott AB, Mascola JR, Kwong PD. Crystal structure, conformational fixation and entry-related interactions of mature ligand-free HIV-1 Env. Nat Struct Mol Biol 2015; 22(7): 522-531

102. Lee JH, Ozorowski G, Ward AB. Cryo-EM structure of a native, fully glycosylated, cleaved HIV-1 envelope trimer. Science 2016; 351(6277): 1043-1048

103. Sharma SK, de Val N, Bale S, Guenaga J, Tran K, Feng Y, Dubrovskaya V, Ward AB, Wyatt RT. Cleavage-independent HIV1 Env trimers engineered as soluble native spike mimetics for vaccine design. Cell Reports 2015; 11(4): 539-550

104. Guenaga J, Garces F, de Val N, Stanfield RL, Dubrovskaya V, Higgins B, Carrette B, Ward AB, Wilson IA, Wyatt RT. Glycine substitution at helix-to-coil transitions facilitates the structural determination of a stabilized subtype C HIV envelope glycoprotein. Immunity 2017; 46(5): 792-803.e3

105. Kong L, He L, de Val N, Vora N, Morris CD, Azadnia P, Sok D, Zhou B, Burton DR, Ward AB, Wilson IA, Zhu J. Uncleaved prefusion-optimized gp140 trimers derived from analysis of HIV-1 envelope metastability. Nat Commun 2016; 7(1): 12040

106. Julien JP, Cupo A, Sok D, Stanfield RL, Lyumkis D, Deller MC, Klasse PJ, Burton DR, Sanders RW, Moore JP, Ward AB, Wilson IA. Crystal structure of a soluble cleaved HIV-1 envelope trimer. Science 2013; 342(6165): 1477-1483

107. Lyumkis D, Julien JP, de Val N, Cupo A, Potter CS, Klasse PJ, Burton DR, Sanders RW, Moore JP, Carragher B, Wilson IA, Ward AB. Cryo-EM structure of a fully glycosylated soluble cleaved HIV-1 envelope trimer. Science 2013; 342(6165): 1484-1490

108. He L, Kumar S, Allen JD, Huang D, Lin X, Mann CJ, SayeFrancisco KL, Copps J, Sarkar A, Blizard GS, Ozorowski G, Sok 
D, Crispin M, Ward AB, Nemazee D, Burton DR, Wilson IA, Zhu J. HIV-1 vaccine design through minimizing envelope metastability. Sci Adv 2018; 4(11): eaau6769

109. Sarkar A, Bale S, Behrens AJ, Kumar S, Sharma SK, de Val N, Pallesen J, Irimia A, Diwanji DC, Stanfield RL, Ward AB, Crispin M, Wyatt RT, Wilson IA. Structure of a cleavage-independent HIV Env recapitulates the glycoprotein architecture of the native cleaved trimer. Nat Commun 2018; 9(1): 1956

110. Wang H, Chen X, Wang D, Yao C, Wang Q, Xie J, Shi X, Xiang Y, Liu W, Zhang L. Epitope-focused immunogens against the CD4binding site of HIV-1 envelope protein induce neutralizing antibodies against auto- and heterologous viruses. J Biol Chem 2018; 293(3): 830-846

111. Zhou T, Georgiev I, Wu X, Yang ZY, Dai K, Finzi A, Kwon YD, Scheid JF, Shi W, Xu L, Yang Y, Zhu J, Nussenzweig MC, Sodroski J, Shapiro L, Nabel GJ, Mascola JR, Kwong PD. Structural basis for broad and potent neutralization of HIV-1 by antibody VRC01. Science 2010; 329(5993): 811-817

112. Freund NT, Horwitz JA, Nogueira L, Sievers SA, Scharf L, Scheid JF, Gazumyan A, Liu C, Velinzon K, Goldenthal A, Sanders RW, Moore JP, Bjorkman PJ, Seaman MS, Walker BD, Klein F, Nussenzweig MC. A new glycan-dependent CD4-binding site neutralizing antibody exerts pressure on HIV-1 in vivo. PLoS Pathog 2015; 11(10): e1005238

113. Borst AJ, Weidle CE, Gray MD, Frenz B, Snijder J, Joyce MG, Georgiev IS, Stewart-Jones GB, Kwong PD, McGuire AT, DiMaio F, Stamatatos L, Pancera M, Veesler D. Germline VRC01 antibody recognition of a modified clade C HIV-1 envelope trimer and a glycosylated HIV-1 gp120 core. eLife 2018; 7: e37688

114. Jardine J, Julien JP, Menis S, Ota T, Kalyuzhniy O, McGuire A, Sok D, Huang PS, MacPherson S, Jones M, Nieusma T, Mathison J, Baker D, Ward AB, Burton DR, Stamatatos L, Nemazee D, Wilson IA, Schief WR. Rational HIV immunogen design to target specific germline B cell receptors. Science 2013; 340(6133): 711716

115. Jardine JG, Kulp DW, Havenar-Daughton C, Sarkar A, Briney B, Sok D, Sesterhenn F, Ereño-Orbea J, Kalyuzhniy O, Deresa I, Hu X, Spencer S, Jones M, Georgeson E, Adachi Y, Kubitz M, deCamp AC, Julien JP, Wilson IA, Burton DR, Crotty S, Schief WR. HIV-1 broadly neutralizing antibody precursor B cells revealed by germline-targeting immunogen. Science 2016; 351 (6280): 1458-1463

116. Pauthner M, Havenar-Daughton C, Sok D, Nkolola JP, Bastidas R, Boopathy AV, Carnathan DG, Chandrashekar A, Cirelli KM, Cottrell CA, Eroshkin AM, Guenaga J, Kaushik K, Kulp DW, Liu J, McCoy LE, Oom AL, Ozorowski G, Post KW, Sharma SK, Steichen JM, de Taeye SW, Tokatlian T, Torrents de la Pena A, Butera ST, LaBranche CC, Montefiori DC, Silvestri G, Wilson IA, Irvine DJ, Sanders RW, Schief WR, Ward AB, Wyatt RT, Barouch DH, Crotty S, Burton DR. Elicitation of robust Tier 2 neutralizing antibody responses in nonhuman primates by HIV envelope trimer immunization using optimized approaches. Immunity 2017; 46(6): 1073-1088.e6

117. Torrents de la Peña A, de Taeye SW, Sliepen K, LaBranche CC, Burger JA, Schermer EE, Montefiori DC, Moore JP, Klasse PJ, Sanders RW. Immunogenicity in rabbits of HIV-1 SOSIP trimers from clades $\mathrm{A}, \mathrm{B}$, and $\mathrm{C}$, given individually, sequentially, or in combination. J Virol 2018; 92(8): e01957-17

118. Sanders RW, van Gils MJ, Derking R, Sok D, Ketas TJ, Burger JA, Ozorowski G, Cupo A, Simonich C, Goo L, Arendt H, Kim HJ, Lee JH, Pugach P, Williams M, Debnath G, Moldt B, van Breemen MJ, Isik G, Medina-Ramírez M, Back JW, Koff WC, Julien JP, Rakasz EG, Seaman MS, Guttman M, Lee KK, Klasse PJ, LaBranche C, Schief WR, Wilson IA, Overbaugh J, Burton DR, Ward AB, Montefiori DC, Dean H, Moore JP. HIV-1 VACCINES. HIV-1 neutralizing antibodies induced by native-like envelope trimers. Science 2015; 349(6244): aac4223

119. Klasse PJ, LaBranche CC, Ketas TJ, Ozorowski G, Cupo A, Pugach P, Ringe RP, Golabek M, van Gils MJ, Guttman M, Lee KK, Wilson IA, Butera ST, Ward AB, Montefiori DC, Sanders RW, Moore JP. Sequential and simultaneous immunization of rabbits with HIV-1 envelope glycoprotein SOSIP.664 trimers from clades A, B and C. PLoS Pathog 2016; 12(9): e1005864

120. de Taeye SW, Ozorowski G, Torrents de la Peña A, Guttman M, Julien JP, van den Kerkhof TL, Burger JA, Pritchard LK, Pugach $\mathrm{P}$, Yasmeen A, Crampton J, Hu J, Bontjer I, Torres JL, Arendt H, DeStefano J, Koff WC, Schuitemaker H, Eggink D, Berkhout B, Dean H, LaBranche C, Crotty S, Crispin M, Montefiori DC, Klasse PJ, Lee KK, Moore JP, Wilson IA, Ward AB, Sanders RW. Immunogenicity of stabilized HIV-1 envelope trimers with reduced exposure of non-neutralizing epitopes. Cell 2015; 163(7): 17021715

121. Hu JK, Crampton JC, Cupo A, Ketas T, van Gils MJ, Sliepen K, de Taeye SW, Sok D, Ozorowski G, Deresa I, Stanfield R, Ward AB, Burton DR, Klasse PJ, Sanders RW, Moore JP, Crotty S. Murine antibody responses to cleaved soluble HIV-1 envelope trimers are highly restricted in specificity. J Virol 2015; 89(20): 10383-10398

122. Feng Y, Tran K, Bale S, Kumar S, Guenaga J, Wilson R, de Val N, Arendt H, DeStefano J, Ward AB, Wyatt RT. Thermostability of well-ordered HIV spikes correlates with the elicitation of autologous Tier 2 neutralizing antibodies. PLoS Pathog 2016; 12 (8): e1005767

123. Koch K, Kalusche S, Torres JL, Stanfield RL, Danquah W, Khazanehdari $\mathrm{K}$, von Briesen $\mathrm{H}$, Geertsma ER, Wilson IA, Wernery U, Koch-Nolte F, Ward AB, Dietrich U. Selection of nanobodies with broad neutralizing potential against primary HIV1 strains using soluble subtype C gp140 envelope trimers. Sci Rep 2017; 7(1): 8390

124. Sok D, Le KM, Vadnais M, Saye-Francisco KL, Jardine JG, Torres JL, Berndsen ZT, Kong L, Stanfield R, Ruiz J, Ramos A, Liang $\mathrm{CH}$, Chen PL, Criscitiello MF, Mwangi W, Wilson IA, Ward AB, Smider VV, Burton DR. Rapid elicitation of broadly neutralizing antibodies to HIV by immunization in cows. Nature 2017; 548 (7665): 108-111 